い。またこの表の No. は第 2 表のそれであるが，この順俑をみ てわかるように二つの成分分子の大きさの相違と, interchange energy の変化の大きさとの間には直接の並行関係は認められな W。

\section{5. 絰括}

従来の理論によれば, 二成分系の定温気液平衡の比較的少数の 例しか表わすことができないことを述べ，分子配直による interchange energy の変化を考虑に入れ，これを表わす係数 $\alpha$ を 導入することによって，さらに広範囲に適用できる $P_{\Lambda} / P_{\Lambda}^{\circ}$ ，
$P_{\mathrm{B}} / P_{\mathrm{B}}^{\circ}$ の理論式を誘導した。

そして二つのバライーター $\alpha$ とリに適当な値を入れることに よって、よく実験值と一致する曲線がえられることを示した。

また，二つの成分分子の大きさの相違と， $\alpha$ または interchange energy の変化の大きさとの間には並行した関係は認められ ないことがわかった。

（昭和 31 年 4 月，日化第 9 年会講湍）

終りに, 御想切な御指導を賜わった，九人坂井渡教授に厚く御 礼申し上げます。

\title{
均一系溶液からの希土類およびトリウムの新しい定量的沈殿法 および希土含有鉱より希土類，トリウムの抽出†
}

(昭和 30 年 10 月 6 日受理)

萩原 善 次 ${ }^{*}$

\section{緒目}

本研究は，米国より奇贈されたモナザイト (Monazite), バス トネサイト (Bastnasite) を用いて, これより希上類, トリウム を迅速，かつ正確に抽出するのを目的として行われた。鈗石を強 酸, または強酸混合物で加熱分解後, 均一系溶液より定量的に希 土類およびトリウムのシュウ酸塩のみを沈段させる。次にこれら シュウ酸塩を酸で分解し，希よよりトリウムを分離する力法を採 用した。モナザイトは上記諸元素の重要資源であるので，本研究 に执いてはモナザイトより, 希土類, トリウムの一抽出法につい て報告する。

予備実験として, 约一溶液から希上類およびトリウムの沈臤生 成が $\mathrm{pH}$-抑制のもとに, ジェチルシュり酸の加水分解を利用して 実施された。さらに鉣石処理を迅速に行5目的で, 溶融法のかわ りに, $60 \% \mathrm{HClO}_{4}$ または $\mathrm{H}_{2} \mathrm{SO}_{4}-\mathrm{HClO}_{4}$ 混合物で加熟分解する 法が採用された。この際トリウム, 希」類の抽浽率を求めた。 抽出率はさきに著者が発表した定量法1)の改艮う式（後述）を其 碟にして求めた。

多くの研究者が過去 10 年間にわたり，モナザイトを用いて， トリウムの分析化学的立場より研究している。モナザイトの分解 に際しては，最近の研究によれば，70\% $\mathrm{HClO}_{4}^{2-3)}, \mathrm{HF}^{2}$ 5) ま たは $\mathrm{KOH}^{6)}$ を用いている。また酸性フッ化カリウム7を用いる 熔融法も効果的であることがわかった。 Moeller らにより 1948

†本報を「希土類元素および随伴元素の分踓法に関する研究 （第 10 報）」とする。闬能は萩原，工化 57,266 (1954).

* 東北大学工学部応用化学科: 仙台甫桜小路.

1) 分析化学討論会 (昭和 26 年 11 月 8 日, 仙台) 希上類の 研究 第 5 報として発表.

2) Louis Gordon et al, Anal. Chem. 21, 1323 (1949).

3) M. Venkataramaniath, C. Laksman Ras, Analyst 77, 103 (1952).

4) N.F. Kember, ibid. 77, 78 (1952).

5) Ingles, Can. Chem. Process Ind. 35, 397 (1951).

6) A.F. Williams, Analyst 77, 297 (1952).

7) C. V. Banks, C. H. Byrd, Anal. Chem. 25, 416 (1953).
年以前になされたこの種の研究8) は紹介されている。

\section{均一溶液加らの沈殿生成}

均一系溶液からの沈段生成を分離の困難な元素間に適用して, 分離を行了試みは近年米国で広く行われている。たとえば，スル ファミン酸, トリクロル酢酸, およびジカルボン酸類が上記目的 で使用された。沈殿を適当な $\mathrm{pH}$ 值を有する熱均一溶液よりつく る際には，もちろん通常の沈殿生成に見られる局部濃度は避ける ことが叮能である。これは沈殷剤が全溶液中で均一に生成される ためである。したがって共沈現象は極端に小さく抑えることがで き，すなわち生成沈段はほとんど不純物を含まぬようになる。一 般に沈殷は密で結晶性であり，かつきわめて口過しやすい特長を 持っている。著者は後述の扫一溶液から沈眨生成を実施し, 基礎 実験絬果を利用してモナズ砂より，トリウム，希上類の抽出を実 施した。

\section{トリウムおよび希士類シュウ酸塭の 均一系溶液加らの沈殿状況}

\section{（a）トリウムによる実験}

メルク製品の硝酸トリウムを硫酸塩にかえ做酸トリウム殠準液 を調製した。標準液は $\mathrm{ThO}_{2}$ として $121.4 \mathrm{mg} / 20.00 \mathrm{ml}$ を含み,

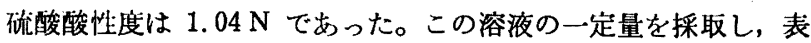
記のごとき実験を実施して,トリウムの沈眨生成と $\mathrm{pH}$ との相互 関係を求めた。使用したシュウ酸ジェチルは，市販品を希炭酸カ リウム溶液で洗浄後, 無水炭酸カリウムを加えて脱水, 次に蒸 留した。実験には $183^{\circ} \mathrm{C}$ 以上の留出物を使用した。

表中カッコで示した濃度は遊離硫酸の概略濃度である。非常に 美しい，口過しやすい沈殿の生成をみた。沈股粒子の大きさは均 一溶液の酸性度の增大とともに大きくなる。トリウムの定量的沈 殿の $\mathrm{pH}$ は第 1 図に示したごとく, 1.1 前後である。

8) Moellor et a], Chem. Rev. 42, 63 (1948). 


实件

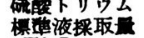
(ThO2

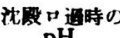
$\left(14 \sim 15{ }^{\circ} \mathrm{C}\right)$

$\mathrm{ThO}_{2}$ 定犆俌

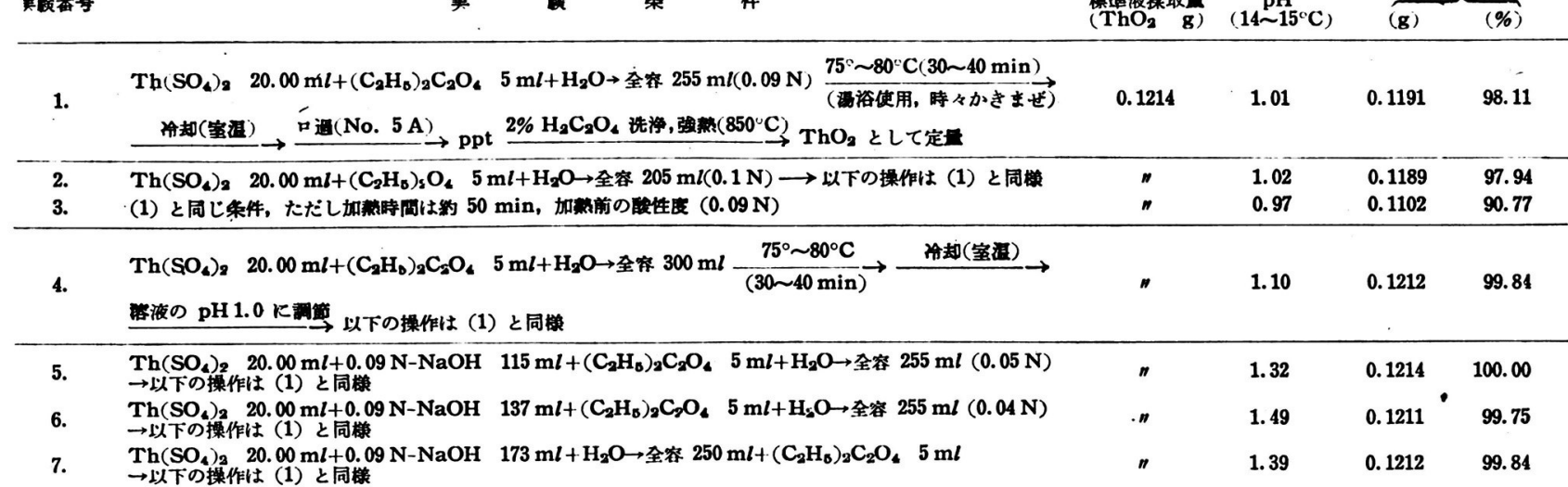

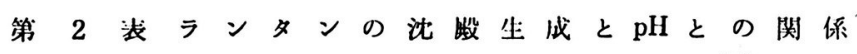

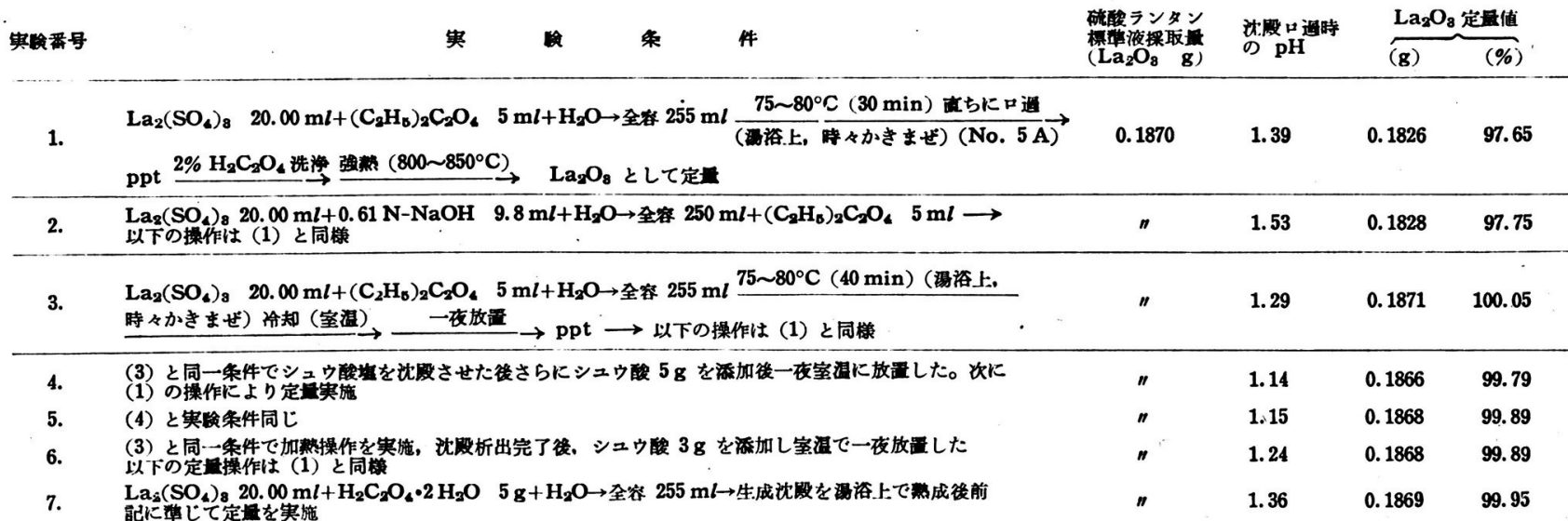

（b）希土類による実畭

(1) ランタンに

よる実験 Kahlbaum の純枠硝酸ランタン を硫酸監にかえ硫酸 ランタン慓準液を調 製した。梆準液は $\mathrm{La}^{3+}$ として0.00797 $\mathrm{g} / \mathrm{ml}$ を含み, それ の硫酸酸性度は0.43 第 1 为 $\mathrm{pH}$ の影警

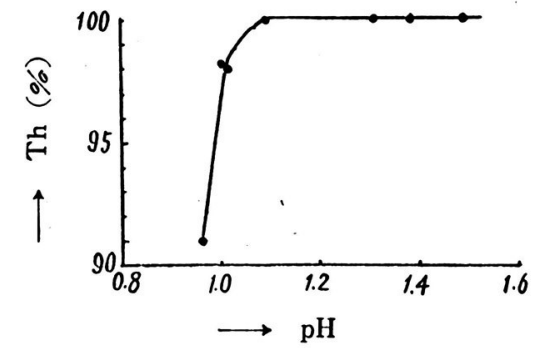

$\mathrm{N}$ に保った。実験は前項に準じた。一定量の $\mathrm{La}^{3+}$ を採取し, シュウ酸ジェチルを加えた後, さらに適量の水で希釈し全容を裴 記のごとく保った。次に湯浴上で加温 $\left(75 \sim 80^{\circ} \mathrm{C}\right)$ し，シュウ酸 ランタンの絬晶を析出させ重量法によって La を定量した。実験 条件と定量值との関係を第 2 表に記載した。

沈殿生成の模様は第 2 図に示した。(a)〜(c) は No.3 と间一 条件で実施したものである。通常の試薬添加による沈殿法と異な り, ある程度の酸性度を与え, かつシュウ酸ジェチルの加水分解 を徐々に行って $\mathrm{C}_{2} \mathrm{O}_{4}{ }^{2-}$ を生ぜしめ, 沈殿生成を行っている故, 最初から美しいよく成長した結晶の析出がビーカー全面より見ら れた。なお比較実験として No. 7 と同一条件で実施した場合の 沈殿の様子を（d）に示した。

著者らの実験条件ではランタンの定量的沈殿時の $\mathrm{pH}$ は約 1.1 以上であることが表からわかる。No. 1,2 は結晶析出後ただちに
第 2 図的一系溶液より $\mathrm{La}_{2}\left(\mathrm{C}_{2} \mathrm{O}_{4}\right)_{3}$ 結晶の生成

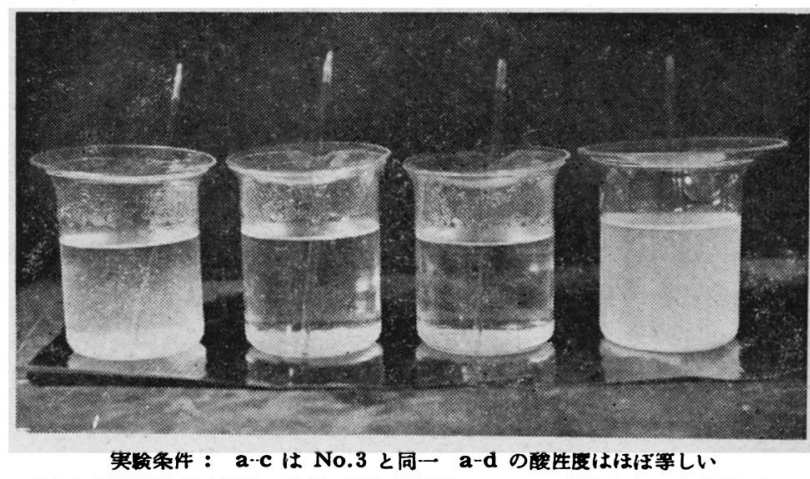

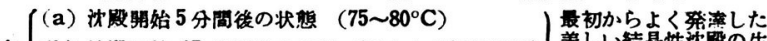

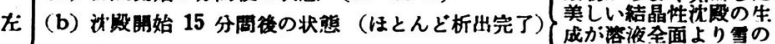

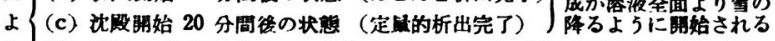

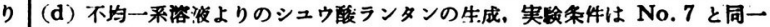

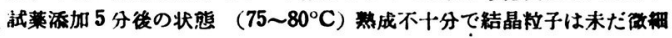

ロ過したもので，温度が高いため溶解度が增大し，定量結果は低 く出ている。これにくらべ沈剘時の $\mathrm{pH}$ がさらに低いものです， 十分放置後定量したものは，好結果を与え $\mathrm{pH} 1.1$ 以上では実験 誤差内で定量が可能なことがわかった。

（ロ）セリウム，ブラセオジムおよびネオジムによる実倹 使 用した硝酸セリウム標準夜は Kahlbaum の純粋な酸化セリウム $\left(\mathrm{CeO}_{2}\right)$ を用いてつくったもので，溶夜は若干硝酸酸性に保った。 重量法による $\mathrm{CeO}_{2}$ 定量值は次のごとくであった。 $\mathrm{CeO}_{2} 0.3100$ $\mathrm{g} / \mathrm{ml}$, 硝酸プラセオジム柾準液は前記会社の硝酸塩を適当量の水 


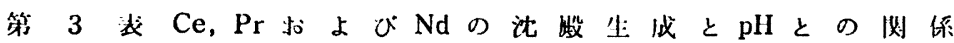

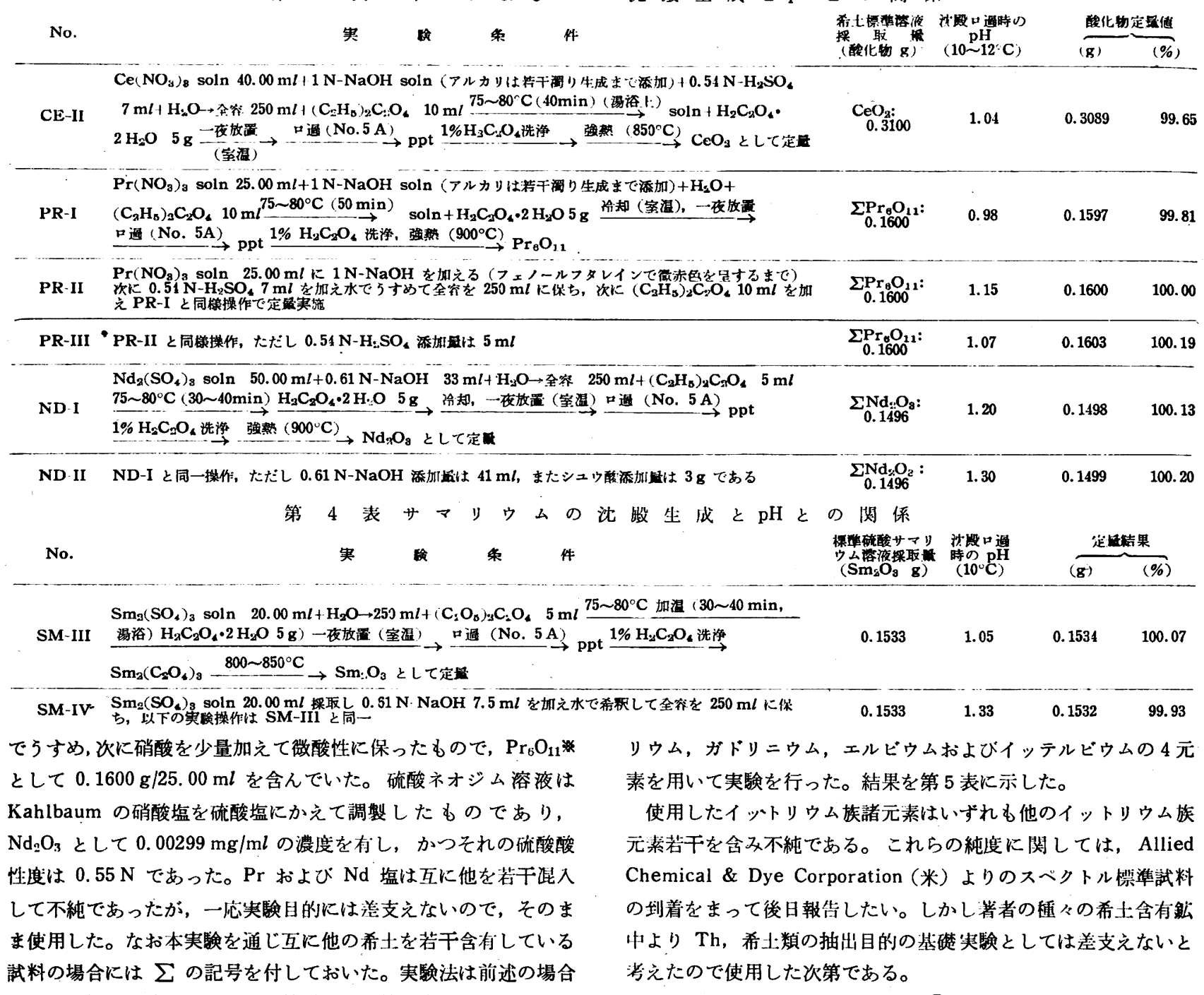

と全く同様の方法であるので，結果のみを第 3 表に示した。

（ハ）サマリウムによる実驗 吸収スペクトルの標準に使用し ている純粉酸化サマリウムに硫酸を加え加熱溶解後, 硫酸サマリ ウム酳準液を調製した。この溶液は若干微酸性に保った。溶液は 酸化サマリウムとして $0.0035 \mathrm{~g} / \mathrm{ml}$ の濃信を有していた。実験例 を第 4 表に示した。表よりわかるごとく $\mathrm{Sm}^{3+}$ は些一系溶液の玔 水分解を利用して pH 1.05 では定畳的に沈殿して来る。

（二）イットリウム族による実験 イットリウム族山，イット

\section{(Y)

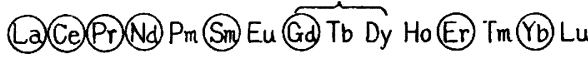

上記希土類元素中, 族号を付した元素に関してシュウ睃ジェチ ルの分水分解を利用して，沶一溶液からの新しい沈股を陚みた絬 果，著者らの実験条件のもとでは，七リウム族は $\mathrm{pH}$ 䄪 1.1 で またイットリウム族は 1.0 内外で定最付に沈諧して来ることがわ かった。上表の塩壆度の強弱を考えれば, 希上シュウ酸塩の溶解 第 5 表イットリウム族の沈橵生成と $\mathrm{pH}$ と成俰

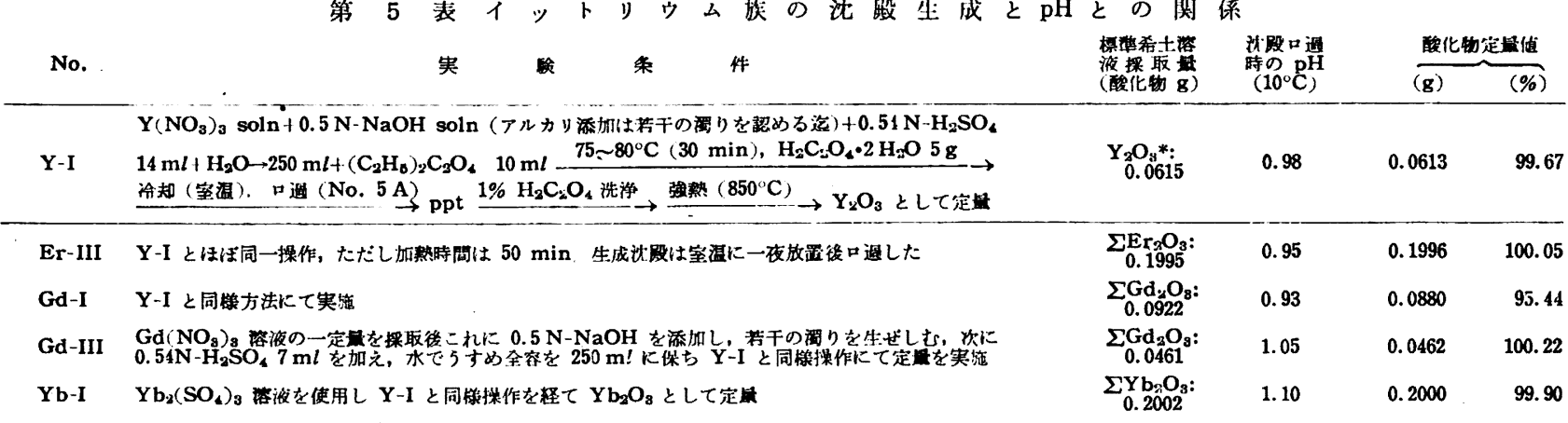

* Yの M.E.W $=96.46^{\circ}$

※ 酸化物の純度 $\operatorname{Pr}_{6} \mathrm{O}_{11} 78.73 \%$ (部細は次報に記载)。
9) Z. Hagiwara, The Technology Reports of the Tohoku University, Vol. XVII, No. 1, p. 85 (1952). 
度は原子番号の增大とともに減少することが予想される。したが って前述の方法による希士類元素の沈殿時の $\mathrm{pH}$ はセりウム族よ りもイットリウム族の柿が若干小になってくると考えられる。

著者は以上の結果を利用して, 希土類, トリウム含有鉣より両 者の迅速抽出を試みたので報告する。 $\mathrm{pH}$ 測定は本報文を通じ “Beckman G pH meter”によった。

\section{モナザイト砂より希土類およびトリゥムの抽出}

前述のごとくモナザイトの分解法は種々提唱されているが，溶 融法等厄介な方法によらず過塩素酸の及, お上び硫酸と過塩素酸 混合物による処理を行い，両者の比較を試みた。本実験は希土鉱 より,トリウム扣よび希土類を工業的規模で抽出する際の予備実 験として行ってみたものである。したがって定量的分解，抽出に 重点をおいていない。

（イ）硫酸一過坆西酸一分解 細粉にして $120^{\circ} \mathrm{C}$ で恒量乾燥した モナザイト砂約 $30 \mathrm{~g}$ を精秤し， $500 \mathrm{ml}$ の硬質丸底フラスコに採 取し, 濃硫酸 $15 \mathrm{ml}$ および $60 \%$ 過塩素酸 $85 \mathrm{ml}$ を加えたのち, 1 時間45分激しく煮沸した。次に室温に冷却を待って conc. $\mathrm{H}_{2} \mathrm{SO}_{4}$ $15 \mathrm{ml}, 3 \% \mathrm{H}_{2} \mathrm{O}_{2} 20 \mathrm{ml}, \mathrm{H}_{2} \mathrm{O} 200 \mathrm{ml}$ を加え, 再び劣沸してから

冷却し口過した。残留物は $3 \mathrm{~N}-\mathrm{H}_{2} \mathrm{SO}_{4}$ 溶液（温）で十分洗浄し, 洗液と口液を合せこれを水で肴欧して全谷を約 $800 \mathrm{ml}$ に保っ た。一夜放消して微量の析出した $\mathrm{SiO}_{2}$ を除いた。口浓を定容フ ラスコに移し全容を 1 l に保った。かかる方法によってえた試料 液の $25.00 \mathrm{ml}$ を $300 \mathrm{ml}$ 内容のビーカーに採取し, $1 \mathrm{~N}-\mathrm{NaOH}$ の適当量を加えたのち水でうすめ全容を $250 \mathrm{ml}$ に保った。次に シュウ酸ジェチル $10 \mathrm{ml}$ を加え前述のごとく $75 \sim 80^{\circ} \mathrm{C}$ に 50 分 間湯浴上で加熱し、シュウ酸塩を沈殿させた。沈殿生成完了は結 晶性沈殿がビーカーの底部に沈降し, 溶液全面よりの結晶の析出 が終止するのでわかる。これにさらにシュウ酸 $3 \mathrm{~g}$ を加えて室温 で一夜放置後口過した。沈殿口過時の溶液の $\mathrm{pH}$ は表記のごとく である。次に沈殿を $1 \%$ シュウ酸溶液（pH 1.15 に調節）で洗 浄後, $900^{\circ} \mathrm{C}$ に強熱して, $\mathrm{ThO}_{2}$ 扣よび全希土酸化物 ( $(\mathrm{RO})$ の合量を求めた。

前述の操作では沈段中に微量の $\mathrm{SiO}_{2}$ の混入のおそれがあるの で, シュウ酸塩沈殿を混酸 $\left(\mathrm{HNO}_{3}+\mathrm{H}_{2} \mathrm{SO}_{4}\right)$ で分解し, $\mathrm{SiO}_{2}$ の除 去を常法操作で実施し, 次に前述の方法で均一系溶液上り再沈殿 を実施してみた。著者の扱った鉱石 $\left(\mathrm{SiO}_{2}\right.$ 含量 $\left.3.86 \%\right)$ では池殿 中へのケイ酸の混入はほとんど問題とならぬ程度のむのでむった。

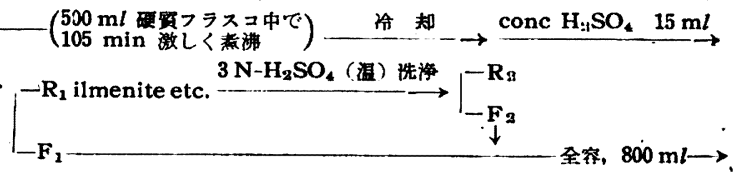

boil，一夜放管。口通（No. 5C)

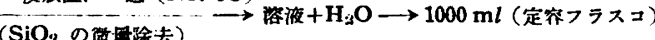

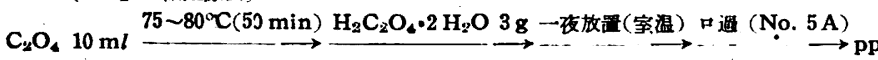

第 6 表 過塩素酸一硫酸 分解法によるトリウム 扎よび希土類の抽出率

\begin{tabular}{|c|c|c|c|c|c|}
\hline \multirow[t]{2}{*}{ No. } & \multirow{2}{*}{ 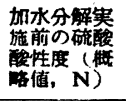 } & \multirow{2}{*}{ 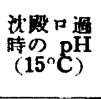 } & \multicolumn{2}{|c|}{ 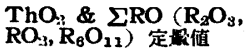 } & \multirow{2}{*}{$\begin{array}{l}\text { 抽消南 } \\
(\%)\end{array}$} \\
\hline & & & (g) & $(\%)$ & \\
\hline M-2-1 & 0.15 & 1.00 & 0.3872 & 50.89 & 80.84 \\
\hline \multirow[t]{2}{*}{ M-2-2 } & 0.1 & 1.12 & 0.3869 & 50.79 & 80.75 \\
\hline & & & & 50.82 & 80.80 \\
\hline M-2-3 & 0.2 & 0.90 & 0.3828 & 50.26 & \\
\hline M-2-4 & 0.25 & 0.91 & 0.3838 & 50.39 & \\
\hline M-2-5 & 0.35 & 0.81 & 0.3837 & 50.38 & \\
\hline$M-2-6$ & - & 0.95 & 0.3837 & 50.38 & \\
\hline
\end{tabular}
る。
$25.00 \mathrm{ml}$ 採取 $+\mathrm{NaOH}(1 \mathrm{~N})+\mathrm{H}_{3} \mathrm{O} \longrightarrow$ 全管 $250 \mathrm{ml}$ (酸性度谓第) $+\left(\mathrm{C}_{2} \mathrm{H}_{5}\right)_{2}$,

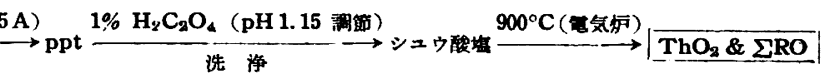

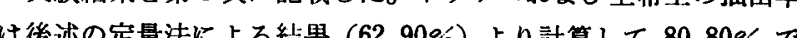
ある。沈㪄生成時の $\mathrm{pH}$ を小にすると表記のごとく两者のそれは 減少してくる。この事実は前節の基礎実験結果より見て当然であ

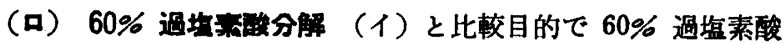
分解法を実施した。実験法はほぼ同一であるので略記しておく。 実験結果を第 7 表に示した。過塩素酸分解法によるトリウムおよ び希土類の抽出率は前述の $\mathrm{HClO}_{4}-\mathrm{H}_{2} \mathrm{SO}_{4}$ - 分解の場合にくらぺ

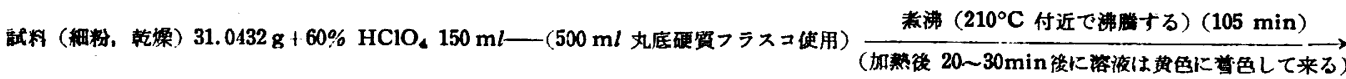

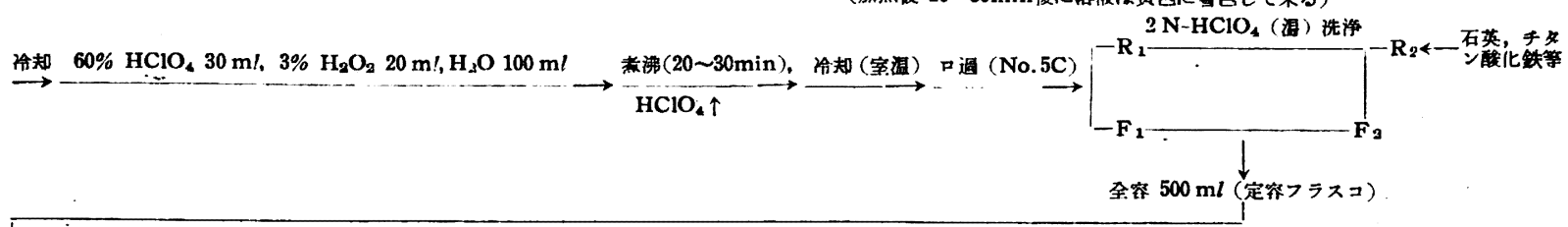

$75 \sim 80^{\circ} \mathrm{C}(40 \sim 50 \mathrm{~min}) \quad \mathrm{H}_{2} \mathrm{C}_{4} \mathrm{O}_{4} \cdot 2 \mathrm{H}_{2} \mathrm{O} 2 \mathrm{~g}$

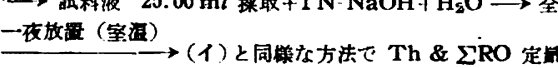

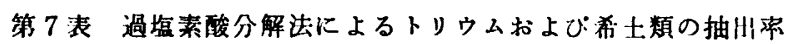

\begin{tabular}{|c|c|c|c|c|}
\hline \multirow[t]{2}{*}{ No. } & \multirow{2}{*}{ 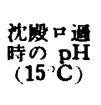 } & \multicolumn{2}{|c|}{ 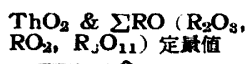 } & \multirow{2}{*}{$\begin{array}{l}\text { 抽出睆 } \\
(\%)\end{array}$} \\
\hline & & $\overline{(\mathrm{g})}$ & $(\%)$ & \\
\hline$M-1 \cdot 1$ & 1.10 & 0.7728 & 49.79 & 79.16 \\
\hline \multirow[t]{2}{*}{ M-1-2 } & 1.14 & 0.7729 & 49.80 & 79.17 \\
\hline & & & 平枃 49.80 & 79.17 \\
\hline M-1-3 & 0.77 & 0.7600 & 48.96 & \\
\hline$M-1-4$ & 0.80 & 0.7650 & 49.29 & \\
\hline M-1-5 & 0,83 & 0.7698 & 49.60 & \\
\hline
\end{tabular}

て若干低い佰を示している。

（ハ）トリウムの抽出 前項（イ〜（ロ）の方法により試料を

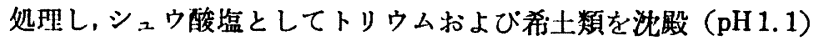
させた後 Gordon および著者の方法（前述）を参照して雨者の分 離を実施した。すなわり下記のごとくシュウ酸塩を過塩素酸塩に かえたのち，加水分解を利用して， pH を 5.4〜6.0 に調節し， 塩基性塩としてトリウムを沈即させ希土類より分離した。 実験結果を第 8９ 表に示した。第8 表は試料を（イ）に準じ 


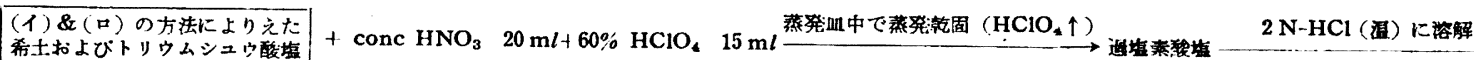

希土およびトリウムシュ酸塩

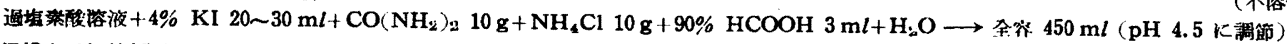

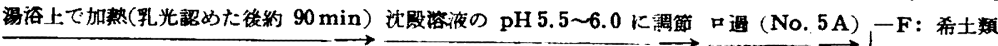

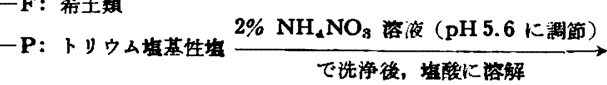

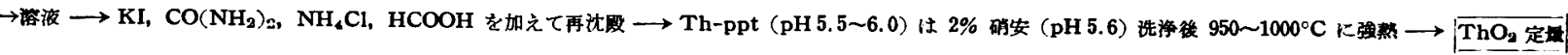

て㴹塩素酸-硫酸で処理し, 第 9 表の值は (口) に準じて過塩素 酸分解を実施してえた結果である。上述のトリウムおよび希け類 の分離操作では第 1 回の操作のみでは希土:類の微量落が混入して くるので再沈股を要する。両表を比較してわかるごとく，师ウ ムの希土鉱よりの抽出率は過塩素酸分解法よりも過塩素酸一硫酸 分解法の方が，やや高い結果を与えている。

\begin{tabular}{|c|c|c|c|c|c|}
\hline \multirow{2}{*}{ No. } & \multirow{2}{*}{ 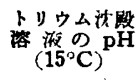 } & \multicolumn{2}{|c|}{$\mathrm{ThO}_{2}$ 定淂値 } & \multirow{2}{*}{ 萑 } & \multirow{2}{*}{ 考 } \\
\hline & & (g) & $(\%)$ & & \\
\hline M-2-10 & 6.0 & 0.0523 & 6.87 & & \\
\hline M-2-11 & 5.9 & 0.0524 & 6.88 & & \\
\hline M-2-13 & 5.8 & 0.0522 & 6.85 & & \\
\hline \multirow[t]{2}{*}{ M-2-14 } & 5.8 & \multirow{2}{*}{\multicolumn{2}{|c|}{$\begin{array}{c}0.0523 \text { 平枃 }-6.87 \\
\end{array}$}} & & \\
\hline & & & & 抽出 & \\
\hline M-2-12 & 5.2 & 0.0401 & 5.27 & & \\
\hline M 2-8 & 6.0 & 0.0579 & 7.60 & 再现敂 & 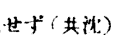 \\
\hline
\end{tabular}

$$
\text { 第成 }
$$

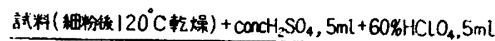

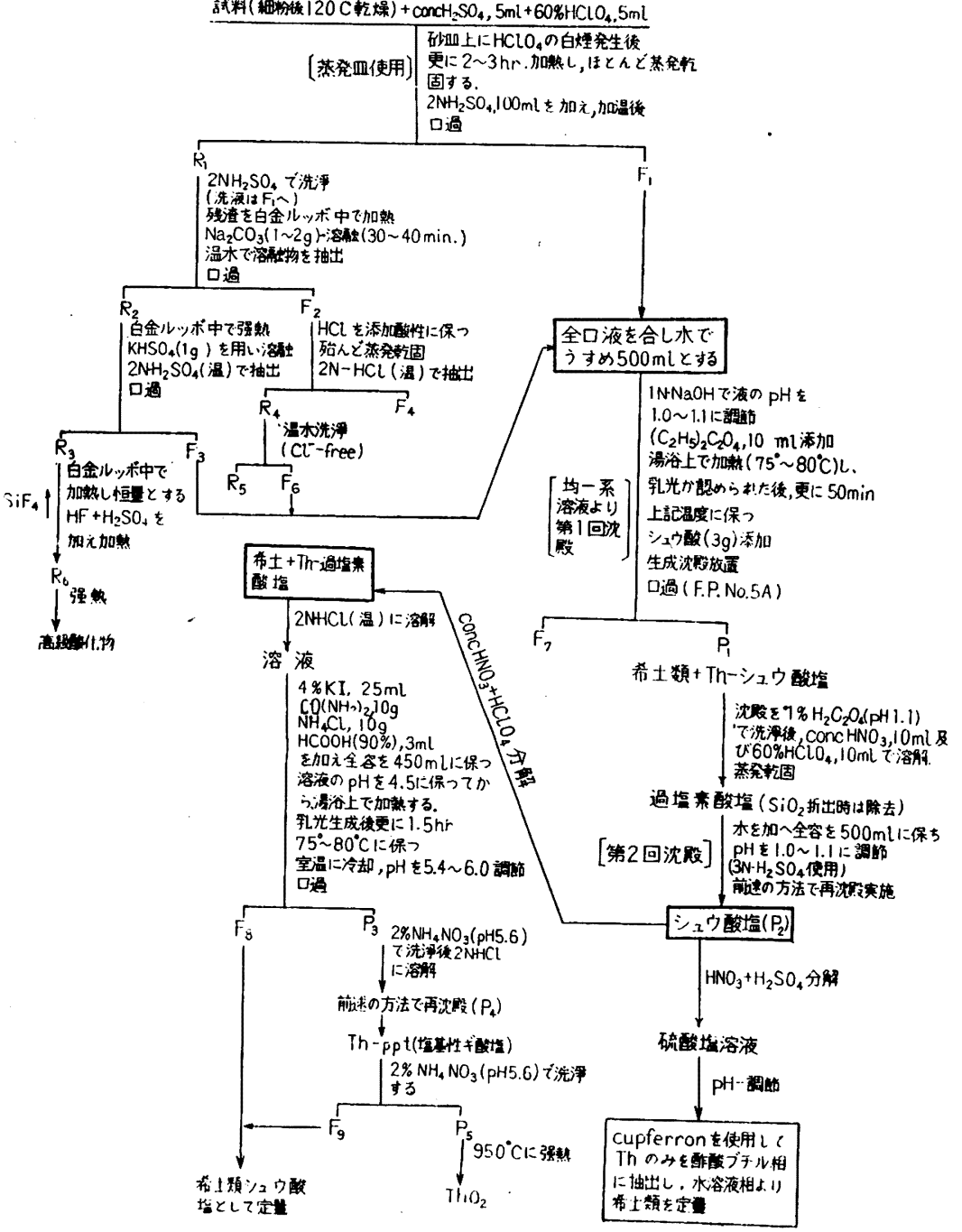

第 9 表 $\mathrm{HClO}_{4}$ 分解によるトリゥムの抽州

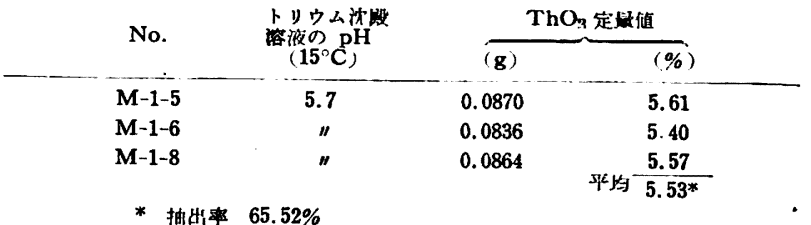

\section{モナザイト砂よリトリゥム, 希土類の 定量的抽出に関する一改良法}

著者は，さきに発表したモナザイトの分析法1)を改良して第 3 図のごとき方式を採用した。料試分解には，硫酸扣よび過塩素酸 混合物を用い砂血上で加熱した。過塩素酸の蒸気発生後 2〜3 時 間さらに加熱を続け，ほとんど蒸発乾固させ，残留物を $2 \mathrm{~N}$ $\mathrm{H}_{2} \mathrm{SO}_{4}$ で浸出した。かかる操作により，試料 の的 $90 \%$ が酸に可溶性に転じた。不溶解残留 物の大部分は，チタン鉄鉱，石英等であった。 残留物は常法にしたがい， $\mathrm{Na}_{2} \mathrm{CO}_{3}$ ，および $\mathrm{KHSO}_{4}$ 溶融を行った。全口液在最後に 500 $\mathrm{ml}$ に保り, $1 \mathrm{~N}-\mathrm{NaOH}$ を用いて, 溶液の $\mathrm{pH}$ を 1.0〜1.1 に調節後, シュウ酸ジェチルを加 え, 加温して均一溶液の加水分解を利用して, トリウムおよび希上類を沈股させた。沈殿を過 塩素酸塩にかえて再沘殿を行った。微量のケイ 酸が混入している場合は再沈殿操作の前で除去 した。希土とトリウムの分嗺には， $\mathrm{pH}$ 抑制に よる方法，および著者の報文結果10)を利用す る二方法をとり入れた。概略を第 3 図に記载す る。

実験結果を第 10 表に記載した。抽出法に関 する詳細は，バストネサイト使用時の実験結果 とともに報告する予定である。

第 10 表 モナザイト中のトリウムおよび

\begin{tabular}{|c|c|c|c|c|c|}
\hline \multirow[t]{2}{*}{ No. } & \multirow{2}{*}{$\begin{array}{c}\text { 䧕料播 } \\
\text { (g) } \\
\text { (g) }\end{array}$} & \multicolumn{2}{|c|}{$\begin{array}{l}\text { Th+希士数の } \\
\text { 酸化物の合地伐 }\end{array}$} & \multicolumn{2}{|c|}{ トリウム定值 } \\
\hline & & (g) & $(\%)$ & (g) & $(\%)$ \\
\hline M-3-1 & 1.2539 & 0.7887 & 62.90 & & \\
\hline M-3-2 & 1.1438 & 0.7193 & 62.89 & & \\
\hline $\mathbf{M}-3-3$ & 0.9876 & 0.6213 & 62.91 & & \\
\hline M 3-4 & 1.3893 & 0.8643 & 62.21 & & \\
\hline M-3-5 & 1.2125 & & & 0.1027 & \\
\hline M 3-6 & 1.1364 & & & 0.0856 & \\
\hline
\end{tabular}
希土類の定量

\section{粉 括}

均一系溶液からの沈殿生成劣，希上類および

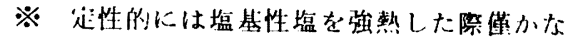
から符出物質湿人を認める

10）萩原, 工化 56, 738 (1953). 
トリウムを用いて実施した。沈殿剤として新たにシュウ酸ジェチ ルが使用された。

モナザイトの分解に際して，過塩素酸，過塩素酸一硫酸の混合 物を用い, 希土類、トリウムの抽出率を求めた。分解能は後者が 若千強力である。前者では上記元素の抽出率は $79 \%$, 後者では
$81 \%$ に及ぶ。

次に前述の基礎実験の条件をとり入れて，モナザイト砂中のト

リウム，希土類の定量法に新しい方式を採用した。

（昭和 30 年 4 月, 日化第 8 年会講演）

終りに御指導いたたいた加藤教授に感謝する。

\section{定量的見地より見たセリウム族希土類元素およびトリウム塩の吸収スペクトル†}

(弨和 30 作 10 月 6 几受理)

$$
\text { 萩 原 善 次* }
$$

\section{実 験 要 旨}

希土含有鉱より 希土類, トリウム、ジルコニウム, ウランな ぞの抽出過程において，分離状況を観察したり，また分離係数 (Separation factor) を求める目的で, La, Ce (III \& IV), Pr, $\mathrm{Nd}, \mathrm{Sm}, \mathrm{Th}$ - 化合物の紫外部扰よび可視部の吸収スペクトル測 定を実施した。なお酸の影響を見るために塩酸, 硝酸, 硫酸およ び過塩素酸の種々の濃度について紫外部吸収を実験した。

サマリウムの $402 \mathrm{~m} \mu$ に扎ける吸収は, 他の希土類の妨害が此 較的少なく定量目的に適合する。サマリウムの $480 \mathrm{~m} \mu$ における 吸収は弱く，かつネオジム，プラセオジムが妨害する。一般にサ マリウム塩の吸収は他のセリウム族のそれに比較して弱い。スリ ット幅 $0.01 \mathrm{~mm}$, 石英吸収槽 $1.003 \mathrm{~cm}$ を用いて実験した結果, $402 \mathrm{~m} \mu$ における極大吸収は $\mathrm{Sm}^{3+} 1 \sim 27 \mathrm{mg}$ 濃度範用内では Beer の法則にしたが5。また上記吸収帯を利用すれば $\mathrm{Sm}^{3+}$ 約 $1 \mathrm{mg} / \mathrm{ml}$ の検出が可能である。分子吸光係数 ( $(\varepsilon) 3.17$, 吸光係 数 $(\kappa) 0.0211$ をえた。

次にセリウムの比色定量法としては, 岸酸塩の過剩存在で黄色 セリウム（IV）錯塩を比色する Telep お゙よび Boltz1) らの方法. 過硫酸塩を加えて, 硫酸酸性溶液（約 $1 \mathrm{~N}$ ) 硝酸銀を触媒として Ce(III) を酸化後, 定量する Medalia, Byrne2) および Freed$\operatorname{man}^{3)}$ らの方法が代表的なものとしてあげられる。著者は新にセ リウム塩 (III) の紫外部吸収実験より, $296 \mathrm{~m} \mu, 254 \mathrm{~m} \mu$ および $240 \mathrm{~m} \mu$ に打ける極大吸収は十分定量目的に適合することを見出 した。スリット幅 $0.30 \mathrm{~mm}, 1.003 \mathrm{~cm}$ 石英吸収槽を用いて次の 結果をえた。カッコ内は Beer の法則にしたが5濃度範用を示 す。定量操作は従来の方法に比較し, 酸化操作を必要とせず簡単 である。な扰妨害イオン等についても検討を加えた。

$$
\begin{array}{lll}
296 \mathrm{~m} \mu: \kappa=0.28 & \varepsilon=3.74 \quad\left(\mathrm{Ce}^{3+} 0.2 \sim 7 \mathrm{mg}\right) \\
254 \mathrm{~m} \mu: \kappa=4.55 & \varepsilon=6.37 \times 10^{2}\left(\mathrm{Ce}^{3+} 10 \sim 200 \gamma\right) \\
240 \mathrm{~m} \mu: \kappa=4.02 & \varepsilon=5.60 \times 10^{2}\left(\mathrm{Ce}^{3+} 10 \sim 200 \gamma\right)
\end{array}
$$

さらにセリウム族塩類の紫外部, 可視部の吸収実験は Rodden ${ }^{4)}$ の測定よりも綿密に行い, $\operatorname{Nd}(523 \mathrm{~m} \mu), \operatorname{Pr}(444 \mathrm{~m} \mu)$ の極大吸収

†本研究を「希土類元雅および随伴元莱の分睢法に関する研 究（第 11 報)」とする.

* 東北大学工学部応用化学科：仙台市桜小路.

1) Telep, Boltz, Anal. Chem. 25, 971 (1953).

2) A. I. Medalia, B. J. Byrne, ibid. 23, 453 (1951).

3) A. J. Freedman, D. N. Hume, ibid. 22, 932 (1950).

4) C. J. Rodden, J. Res. Nat. Bur. Stand. 26, 557 (1941).
を利用して，希土混合物中の両者の定量を実施してみた。

$$
\text { 实 験 の 部 }
$$

\section{測 定 装 贯}

島津 QB-50 型光電分光光度計を使用した。光源には $350 \mathrm{~m} \mu$ 以下の紫外部の測定には水素放電管を，また $350 \sim 800 \mathrm{~m} \mu$ の波 長域ではタングステン灯を用いた。吸収槽は $1.003 \mathrm{~cm}$ 石英吸収 槽を全波長域にわたり使用した。それは使用前希硝酸で十分洗浄 し，かつ常法にしたがって吸光度補正を行った。波長校正は製造 者により指示されたごとく，水素電管を用いて水素の $6563 \AA$ の 発光スペクトル線を標準として随時実施した。

\section{昍収スペクトルの測定}

希上類，無機塩類の多くは可視部，近紫外部にわたって通常の 金属化合物に比較して特長ある尖鋭な吸収带を示す傾向が強い。 Rodden の研究() 以前にも混合物中の二, 三の元素を定量する目 的で，希土類の吸収スペクトルに関する研究が行われた。たとえ ば Prandtl, Scheiner 5) らは特定の吸収帯を選択して標準溶液の 吸収の強さと同じになるまで試料液を希釈する方法を利用して研 笢を実施した。Hass ${ }^{6)}$ はプラセオジム, ネオジムの混合物中の 両者を定量する目的で, 特定の吸収帯を選び, それの消隇するま で希釈する方法を採用した。さらにフィルター光電比色計を使用 する方法 ${ }^{7-8)}$ も，前記目的に対し利用された。しかしながらフィ ルターの特性曲線から見て明らかなよ5に, 希士類の狭い吸収帯 を完全に分離することは不可能であるから，それの利用は適当で ないと考えられる。

最近 Moeller ら9)は数種の希上とナフタザリンの反応により生 成するキレート化合物没 の叹に関して報告しているが，個々の 吸収帯は重なり, 定量目的には不適当と考えられる。本実験にお いては有機緹塩を利用せずに, 希上の無機塩のみを使用した。紫

5) Prandtl, Scheiner, Z. anorg. allgem. Chem. 220, 107 (1934).

6) Hass, Beitr. Kenntnis $\operatorname{Pr}$ u. Nd Dissert. Berlin 47, 51,54 (1920).

7) O.S. Plantinger, A Study of the Colorimetric Detn. Dissertation, New York Univ. (1934).

8) B. A. Brice, Rev. Sci. Ind. 8, 279 (1937).

9) T. Moeller, M. Tecotzky, J. Am. Chem. Soc. 77. 2649 (1955).

※ たとえば La, Pr, Nd, Sm おょび Y の Naphthazarin 錯塩の $5200,5600,6065 \AA$ 付近の吸収帯は相当強いが, 上記希:士錯塩の吸収带は重なり, 特異性は認められない。 